http://kitaibelia.unideb.hu/

ISSN 2064-4507 (Online) • ISSN 1219-9672 (Print)

(C) Department of Botany, University of Debrecen, Hungary

23 (2): 179-187.; 2018

DOI: $10.17542 /$ kit.23.179

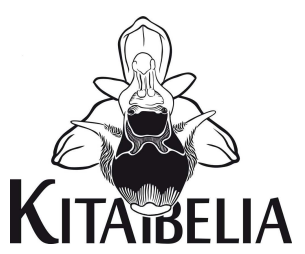

\title{
A potenciálisan inváziós vesszős aggófü (Senecio inaequidens DC.) aktuális elterjedése Magyarországon
}

\author{
HASZONITS Győző \& ScHMIDT Dávid \\ Soproni Egyetem, Erdőmérnöki Kar, Növénytani és Természetvédelmi Intézet

\section{Current distribution of the potentially invasive narrow-leaved ragwort} \\ (Senecio inaequidens DC.) in Hungary
}

\begin{abstract}
Our study presents the actual status of potentially invasive Senecio inaequidens in Hungary. Literary and herbarium data are also discussed. We report some new data from ruderal places and near highways which are unmarked until now. The actualized distributional map of the species are given. We sign the potential habitat threats too.
\end{abstract}

Keywords: plant invasion, neophyte, linear facilities

Összefoglalás - Munkánkban a dél-afrikai eredetű, hazánkban potenciális özönnövénynek számító Senecio inaequidens magyarországi előfordulási adatait foglaljuk össze, valamint beszámolunk néhány újabb hazai megtelepedéséről. Irodalmi, herbáriumi, illetve saját adatokat összegeztünk, valamint aktualizáltuk a faj elterjedési térképét. Szemléltetjük a faj inváziójának aktuális stádiumát és a természetközeli élőhelyekre jelentett lehetséges veszélyeit.

Kulcsszavak: növényi invázió, újjövevénynövény, vonalas létesítmények

\section{Bevezetés}

A cikkben tárgyalt faj első példányaira 20 éve bukkantak az országban, amikor a hazánktól nyugatra észlelhető határozott inváziója miatt nálunk is gyors terjedését prognosztizálták (DANCZA \& KiRÁLY 2000). Európai léptékben kiemelten veszélyes özönfajról lévén szó [1], terjedésének folyamatos térképezése és élőhelyspektruma bővülésének dokumentálása kívánatos, amely komoly segítséget jelenthet a gyakorlati természetvédelmi beavatkozások szükségességének mérlegelésénél. Célunk a korábbi előfordulási adatok összegyűjtése és rendszerezése, újabb élőhelyi és lelőhelyadatainak közlése, valamint elterjedési térképének aktualizálása volt.

\section{Irodalmi áttekintés}

A dél-afrikai eredetű, chamaefiton életformájú vesszős aggófü (Senecio inaequidens DC.) az Európai és Földközi-tenger Melléki Növényvédelmi Szervezet (EPPO) listáján a legjelentősebb gazdasági kárt okozó, nemzetközi szinten kiemelt, inváziós gyomnövények között sze- 
repel [1]. Terjedési potenciáljára jellemző, hogy egyetlen egyede több mint 10 000, de akár 29000 magot is produkálhat (LÓPEZ-GARCÍA \& MAILLET 2005), amelyek 30-40 évig is életképesek maradhatnak a talajban (HEGER \& BöHMER 2006). Invázióbiológiai és természetvédelmi szempontból aggodalomra adhat okot hosszúra nyúlt vegetációs ciklusa, illetve nagyfokú hidegtürése. A magérlelési időszak nagyon hosszú, ezáltal „fertőzési” lehetőségei is arányosan növekednek.

A faj európai térhódítását az 1800-as évek végétől kísérik figyelemmel. Feltehetőleg az 1880-as években került Európába, dél-afrikai gyapjú-szállítmányokkal (WAGENITZ 1987, BORNKAMm 2002). Az első ilyen jellegű irodalmi adata Németországból (Hannover) származik, 1889-es dátummal (WAGENITZ 1987). A későbbi évtizedekben számos európai szerző beszámol a faj felbukkanásáról és térhódításáról, az ezredfordulóig napvilágot látott szakirodalom összefoglalását lásd DANCZA \& KIRÁLY (2000) munkájában. Az 1970-es évekre jelentős gyomként lépett fel szántóföldi (különösen szőlőhegyi) kultúrákban, valamint utak mentén és legelőkön Franciaországban (LóPEZ-GARCíA \& MAILLET 2005). Közép-Európa keleti részét az 1990-es évekre érte el: Lengyelországban 1987-ben (ERNST 1998), Montenegróban 1990-ben (StEvanović et al. 1990-1991), Szlovéniában 1992-ben (KAligarič 1992), BoszniaHercegovinában 1996-ban (MASLO 2014), Szlovákiában 1997-ben (JEHLík 1998), Romániában 2008-ban (ANASTASIU \& NEGREAN 2008), Bulgáriában 2009-ben (Vladimirov \& PETRova 2009), Horvátországban 2012-ben (MıLović \& PANDŽA 2015) találták az első példányokat. Jelenléte a gyorsforgalmú autóutak mentén már az 1980-as évektől dokumentált Németországban (RADKOWITSCH 2003), keleti irányban azonban csak jóval később, a 2000-es évektől figyelték meg (HoHLA 2011, KoCIÁN 2014, 2016). Közép- és Kelet-Európában további térhódítására figyelmeztetnek (SIRBU \& OPREA 2010, KoCIÁN 2016), fokozódó lengyelországi terjedéséről PLISZKo (2017) számol be részletesen.

Magyarországi első adata a dinnyési vasútállomásról származik (BARABÁs \& RÉDEI 1998). Jól ismert, hogy a növényt elsőként tévesen Senecio squalidus-ként publikálták. Az adat helyesbítését, egyszersmind a fajról szerzett első hazai megfigyeléseket, továbbá az alaktani és ökológiai jellemzőket DANCZA \& KIRÁLY (2000) publikálta. Később a növénnyel nem foglalkoztak kiemelten, adatai szórványosan bukkannak fel florisztikai jellegű munkákban. Győr környéki előfordulási adatait SCHMIDT \& BAUER (2005) és SCHMIDT (2010) ismerteti, KIRÁLY et al. (2009) néhány kis egyedszámú új populációt közöl, megjegyezve, hogy „tömeges terjedéséről semmiképpen nem beszélhetünk". Elterjedésének flóratérkép-alapú ábrázolását DANCZA (2012), majd BARTHA et al. (2015) mutatja be. A faj BALOGH et al. (2004) listáján, mint meghonosodott neofiton, CSISZÁr (2012) kötetében pedig már inváziós fajként szerepel.

\section{Anyag és módszer}

Munkánk során összegeztük a fajról szerezett eddigi hazai ismeretanyagot. Összegyűjtöttük és rendszereztük a korábbi publikációk adatait. Az adatokat egységesen lokalizáltuk, az alábbi sorrendet tartva: földrajzi középtáj (DövÉNYI 2010 alapján), településhatár, szerző által közölt lelőhely, KEF-kód. Feldolgoztuk a faj herbáriumi adatait, amelyeket digitalizált formában a Magyar Természettudományi Múzeum (MTM Növénytára) és a Debreceni Egyetem (DE) munkatársai bocsájtottak rendelkezésünkre. Aktuális, saját terepi kutatásaink során a faj további, eddig nem publikált adatait gyűjtöttük, amelyeket itt teszünk közzé. Újonnan megtalált lelőhelyein társulástani típusfelvételt készítettünk. 


\section{Eredmények}

A hazai főközlekedési utak mentén végzett útökológiai és florisztikai megfigyelések során lettünk figyelmesek az M1-es autópálya Győr - Budapest közötti szakaszán a faj több új lelőhelyére. Győr és Sopron környéki terepbejárások alkalmával törmelékhalmokon, folyótöltésen, homoki erdőben, valamint felhagyott kőbányában leltünk rá további példányaira. Ezek az élőhelyek az eddig publikált hazai előfordulási körülményeihez képest újdonságot jelentenek. A szakirodalom mindössze egy lelőhelyet közöl parlagról Bakonybánk mellől (RIEZING 2012).

Megjelenésének első évtizedében a vasúti töltések köves pionír termőhelyeit preferálta (vö. DANCZA \& KiRÁLY 2000), terjedése azonban az eltelt 20 év alatt alig változott, sőt, a Kelenföldi pályaudvaron a pályatest hatékony gyomirtásának köszönhetően egyedeinek száma jelentősen csökkent (DANCZA 2012), és hasonló megtorpanás, illetve visszaszorulás következett be Győr-Gyárvárosban is. Megfigyeléseink szerint vasutak mentén állományai továbbra sem gyarapodnak, ismert lelőhelyei az elmúlt 10 év alatt gyakorlatilag változatlanok maradtak. Megjegyzendő, hogy a növény vasútvonalak menti előfordulását - tudomásunk szerint teljességre törekvő módon nem kutatták, ismert lelőhelyeinek többségén látványos, akár vonatból is azonosítható nagyobb populációk vannak jelen. Időben legkésőbbről származó vasút melletti jelzése (Szentgotthárd, 2015) egyetlen erőteljes, rendszeresen lekaszált példányt takar, amely kétségkívül már sokkal régebben megtelepedhetett. Érdekes azonban, hogy a legrégebben ismert vasút melletti gócpontjai környékén a növény „kilépett” a vasúti sínek közül, és többfelé megjelentek egyedei a vasúti pályákkal szomszédos autóutak mentén. Így Budapesten a Lágymányosi híd környékén (DANCZA 2012), Kelenföldön az Etele téren (Somlyay 2014 in BP, Schmidt D. ined.) és Ferencvárosban az Illatos úti aluljárónál (Schmidt D. ined.), továbbá Győrött a Fehérvári úti felüljáró töltésén (Schmidt D. ined.). Inváziós mértékű terjedésbe azonban ilyen élőhelyeken nem kezdett sehol sem. Vasútvonalaktól független, napjainkban megfigyelhető újabb (enyhe) terjedési hulláma forgalmas főutak, elsősorban autópályák (egyelőre csak az M1-es) mentén alakult ki, de antropogén hatásoknak erősen kitett felszíneken is több helyen megjelentek egyedei. Ilyen jellegű területekről a faj 2017-ben öt újabb lelőhelyről került elő. Tudomásunkra jutott, hogy egy homok alapkőzeten kialakult, minimális zavarásnak kitett legelőn megjelenése tömegessé vált (Szabó R. ex verb.). Lelőhelyei számának és élőhelyspektrumának az elmúlt közel két évtized alatt bekövetkezett változását az 1. ábra szemlélteti.

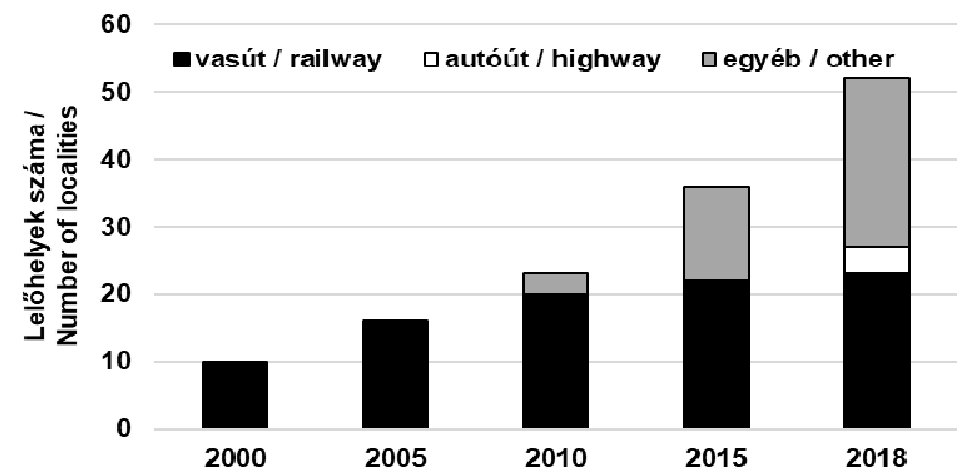

1. ábra. A Senecio inaequidens ismert lelőhelyeinek és élőhelyspektrumának változása 2000 és 2018 között Fig. 1. Known localities and changing of habitat spectrum of Senecio inaequidens between 2000 and 2018 


\section{A Senecio inaequidens eddig ismert hazai előfordulásai}

A felsorolás összesen 52 adatot tartalmaz. Szakirodalmi források 32 lelőhelyet említenek, a feldolgozott herbáriumi példányok száma nyolc. A herbáriumi példányok közül három adat: Budapest: Etele tér (Somlyay L. 2014), Ferencváros (Bauer N. 2007), illetve Nyékládháza (Süveges K. 2015), nem kapcsolódik irodalmi említéshez. A publikálatlan megfigyelések száma 20, amelyből 12 adat az elmúlt évekből származó saját megfigyelésünk, kettő Szabó Roland szóbeli közlése alapján került feldolgozásra, egy Süveges Kristóf Nyékládházán gyűjtött egyedének közöletlen herbáriumi példánya, egy Somlyay Lajos Etele téri gyűjtése, egy pedig Bauer Norbert Ferencvárosi gyưjtése, a fennmaradó három a Flóraatlaszban megjelenő, önállóan nem közölt megfigyelés. BARTHA et al. (2015) térképén összesen 19 flóratérképezési kvadrátban van jelezve a faj, az újabb megfigyelésekkel bővülve ez a szám 28-ra emelkedett (2. ábra.). Említést érdemel, hogy hazánkban Budapesttől keletre három lelőhelyről került elő a közelmúltban. Süveges Kristóf figyelte meg egy Nyékládháza melletti kavicsbányában, illetve Szabó Roland felhagyott legelőkön. Érdekesség, hogy mind a három lelőhely távol esik mindennemű vonalas létesítménytől.

Alpokalja

- Balogunyom: „Ják-Balogunyom vasútállomás vágányai mellett, néhány tő (2006)” [8865.2] (KirálY et al. 2009).

- Fertőrákos: Felhagyott kőfejtőben, pionír felszínen egy tő [8265.4] (Haszonits Gy. 2017 ined.).

- Szentgotthárd: „Vasútállomás: egy tő” [9063.2] (Schmidt D. in BARTHA et al. 2015).

Bakony-vidék

• Bakonybánk: „Lázi-úti-dűlő, parlagon 1 tő” (2011) [8573.1] (RIEZING 2012).

Dunamenti-síkság

- Budapest: V. kerület [8580.1] (PIFKó D. in BARTHA et al. 2015).

- Budapest: „A Lágymányosi-híd alatt évente 1-2 alkalommal kaszált gyomtársulásokban” [8580.1] (DANCZA 2007-2008 in KIRÁLY et al. 2009).

- Budapest: „Rákosrendező pályaudvar” [8480.4] (TERPó \& BÁLINT in DANCZA \& KirÁlY 2000).

- Budapest: Kelenföldi pályaudvar (TERPó 1998a, 1998b), „a Kelenföldi pályaudvar legforgalmasabb sínjei között, a tehervágányok, valamint a peronok mentén előfordulása tömeges” [8580.1] (DANCZA et KIRÁLY 1998 in DANCZA \& KIRÁLY 2000).

- Budapest: „Keleti pályaudvar, számos példány vágányok mellett” [8580.2] (KIRÁLY 1999 in DANCZA \& KIRÁLY 2000).

- Budapest: „Ferencvárosi pályaudvar” [8580.2] (DANCZA 1999 in DANCZA \& KiRÁLY 2000).

- Budapest: „Keleti pályaudvar előtti virágágy (1 tő)” [8480.4] (KERÉNYI-NAGY et al. 2016).

- Budapest: „Istvánmezei út 3-5. (1 tő)” [8480.4] (KeRÉNYI-NAGY et al. 2016).

- Budapest: „Kőbányai úti villamossínek mentén az Orczy út és Könyves Kálmán körút közti teljes szakaszon (legalább 600 tő)” [8580.2] (KERÉNYI-NAGY et al. 2016).

- Budapest: „A volt »Tigris Piac« teljes területén (legalább 800 tő)” [8580.2] (KERÉNYI-NAGY et al. 2016).

- Budapest: „Hungária körút - Salgótarjáni út sarka (1 tő)” [8580.2] (KERÉNYI-NAGY et al. 2016).

- Budapest: „Kárpáti Zoltán sétány Kőbányai út felé eső vége (3 tő)” [8580.2] (KERÉNYINAGY et al. 2016).

- Budapest: Etele tér, „Etele tér P2 P+R parkoló” köves szegélyein [8580.1] (Schmidt D. 2018 ined.).

- Budapest: Ferencváros, Illatos úti aluljáró rézsűjén erőteljes példányok [8580.2] (Schmidt D. 2018 ined.). 
- Budapest: „Kelenföld (pályaudvar)” [8580.1] (Dancza I. 1999 (BP) in DANCZA \& KiRÁLY 2000).

- Budapest: „Kelenföld, pályaudvar, a vágányok között, 120 m s. m.” [8580.1] (KIRÁLY G. 1999 in DANCZA \& KIRÁLY 2000).

- Budapest: „Ferencvárosi villamosgarázs, ad latera viarum” [8580.2] (Bauer N. 2007 in BP).

- Budapest: „XI. ker., Etele tér, parkoló melletti gyomtársulásban” [8580.1] (Somlyay L. 2014 in BP).

- Fülöpszállás: A településtől északra fekvő, cserjésedésnek indult felhagyott legelőn tömeges, homok alapkőzeten [9181.3] (Szabó R. 2018 ex verb.).

Duna-Tisza közi síkvidék

- Pusztavacs: A település keleti határában fekvő cserjésedő legelőn 1 terebélyes tő, homok alapkőzeten [8883.1] (Szabó R. 2015 ex verb.).

Dunazug-hegyvidék

- Bicske: „Vasútállomás, több egyed vágányok között” [8577.1] (KIRÁLY 1999 in DANCZA \& KIRÁlY 2000).

- Óbarok: M1-es autópálya, Óbarok pihenő, egy tő [8477.3] (Haszonits Gy. \& Schmidt D. 2017 ined.).

- Zsámbék: M1-es autópálya, Zsámbéki pihenő környékén, az elválasztósávban többfelé [8478.3] (Haszonits Gy. \& Schmidt D. 2017 ined.).

Észak-Alföldi Hordalékkúp-síkság

- Nyékládháza: „Kavicsbánya” [8091.1] (Süveges K. 2015 in DE).

Győri-medence

- Csorna: A 86-os számú főút padkáján, Csorna központjától kb 3,5 km-re, 1 terebélyes példány [8369.3] (Haszonits Gy. 2018 ined.).

- Győr: „Az új Bácsai út építési területén 1 példány” [8271.4] (SchmidT \& BAUER 2005).

- Győr-Gyirmót: „Az É-D-i gátúttól Ny-ra útszéli törmelékkupacon (2007)” [8371.3] (SCHMidT 2010).

- Győr: Nádorváros, Nádor aluljáró mellett 1 nagyobb bokor [8371.2] (Schmidt D. 2014 ined.).

- Győr: Raktárvárosnál a veszprémi vasútvonal mellett, 1 tő [8371.4] (Schmidt D. 2014 ined.).

- Hegyeshalom: „A vasútállomás Ny-i részén, a vágányok között néhány tő” [8068.4] (DANCZA I. 2006 in KiRÁlY et al. 2009).

- Levél [8169.1] (Király G. in BARTHA et al. 2015)

- Mosonmagyaróvár [8169.4] (Király G. in BARTHA et al. 2015)

Komárom-Esztergomi-síkság

- Almásfüzitő: „A pályaudvar keleti részén vágányok között néhány tő” [8275.4] (DANCZA 2000 in DANCZA \& KIRÁLY 2000)

- Győr: „Ipartelepek (Győr-Gyárváros vasúti megálló) vágányok mellett szórványosan” [8371.2] (JENEI E. 1999 in DANCZA \& KirÁLY 2000).

- Győr: „A győri teherpályaudvar vágányai között; Belváros: a Baross híd és a gyaloghíd között, vágányok mellett” [8371.2] (SCHMIDT \& BAUER 2005).

- Győr: „Ipartelepek, Győr Gyárváros vasúti megállótól 1 km-re keletre a vasúti sínek mentén, néhány tő" [8372.1] (KIRÁLY 2000 in DANCZA \& KIRÁLY 2000).

- Győr: „Gyárváros: a vasúti megállótól K-i irányban kb. 300 m-en keresztül a vágányok közötti kőzúzalékon; a Vágóhíd melletti ipari szárnyvonal mellett” [8372.1] (SCHMIDT \& BAUER 2005).

- Győr: „Szentiváni-erdő, ültetett fenyves degradált részén 1 példány” [8272.3] (SCHMIDT D. in BARTHA et al. 2015). 
- Győr: Likócstól ÉK-re a Duna töltésének a végénél, ruderális gyomtársulásban 1 tő [8272.3] (Schmidt D. 2012 ined.).

- Győr: Kiskút, Ipar-csatorna töltésén friss gyomtársulásban 1 tő [8372.1] (Schmidt D. 2016 ined.).

- Győr: Gyárváros, Szeszgyári iparvágány mentén a Fehérvári úti felüljáró és az Interspar között szórványos [8371.2] (Schmidt D. 2017 ined.).

- Komárom: „Vágányok mellett a Csillag-erődnél” [8274.4] (SCHMIDT \& BAUER 2005).

- Nagyszentjános: „A vasútállomás közelében” [8273.3] (SCHMIDT \& BAUER 2005).

Mezőföld

- Dinnyés: „Vasútállomás, a vágányok menti ruderális gyomközösségben, cca. 150 m s. m.” [8877.1] (Barabás S. 1998 in BP) (sub nomine Senecio squalidus L.).

- Dinnyés: „Vasútállomás, a sínek között” [8877.1] (JENEY E. 1999 in DANCZA \& KiRÁLY 2000).

- Pákozd: [8877.1] (ILlYÉs Z. in BARTHA et al. 2015).

Sopron-Vasi-síkság

- Nagycenk: „A vasútállomás tehervágánya mellett, egyetlen tő” [8366.3] (KIRÁLY G. 2006 in KIRÁLY et al. 2009).

Vértes-Velencei-hegyvidék

- Tatabánya: M1-es autópálya 55. km-nél, elválasztósávban egy tő [8476.2] (Haszonits Gy. \& Schmidt D. 2017 ined.)

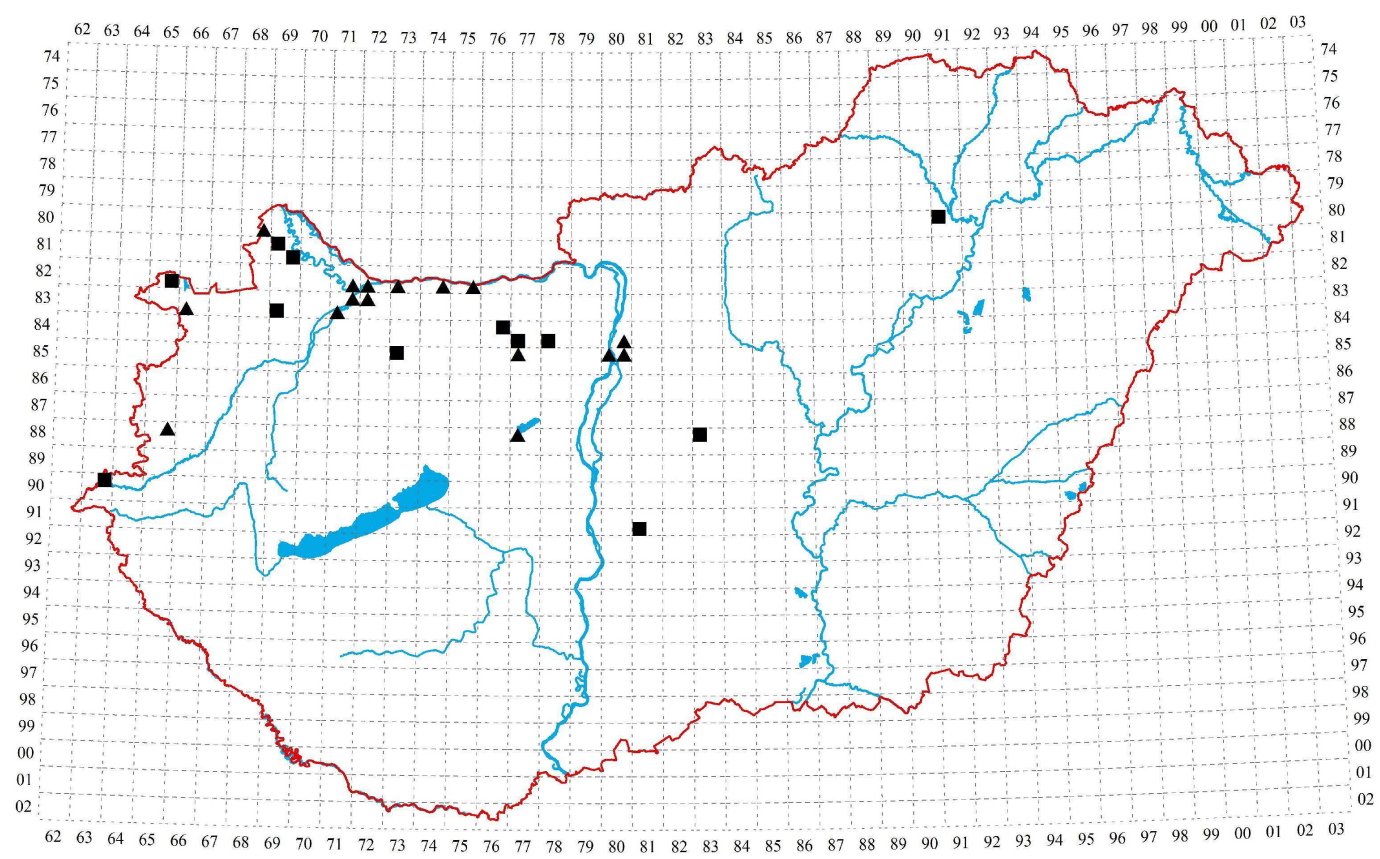

2. ábra. A Senecio inaequidens elterjedése Magyarországon 2018-ban (alaptérkép: BARTHA et al. 2015) (Jelmagyarázat: háromszög: 2010-ig ismert előfordulás; négyzet: előfordulás 2010 után)

Fig. 2. Distribution of Senecio inaequidens in Hungary in 2018 (basic map: BARTHA et al. 2015)

(Legend: triangle: known localities until 2010; square: new localities after 2010)

\section{Termőhelyi környezet}

Frissebb adataink közül az egyik a Fertőrákostól Fertőmeggyes (Mörbisch) felé vezető műúttól nyugati irányban elhelyezkedő felhagyott kőbányából származik. Egészen hasonló élő- 
helyről jelzi előfordulását Szlovákiában KoŠŤÁL $(2012,2015)$. A terület java részén a talajképződés kezdeti stádiumban van, így zömmel váztalajok, illetve nyers mészkőtörmelékes felszínek a jellemzők. A talajfejlődés lassúságához nagymértékben hozzájárul a defláció, valamint az erózió is. Mivel e talajok víztartó képessége meglehetősen csekély, így a terület alapjában véve igen száraz, valamint a gyér növényzet miatt könnyen felmelegedő is. A fellelhető növényzet is ezekre a körülményekre enged következtetni.

A fás vegetáció kimerül a Pinus nigra, a Betula pendula, a Robinia pseudoacacia és a Populus xeuramericana szálankénti megjelenésében. Cserjék közül jellemző a Rhamnus catharticus, Rosa canina, Ligustrum ovalifolium, illetve a Hippophaë rhamnoides. Az utóbbi kettő minden bizonnyal szándékos betelepítéssel (sövénylétesítés) került a kőfejtőbe.

A lelőhely környékén nagy számban képviseltetik magukat a következő lágyszárú növények: Sanguisorba minor, Sedum rupestre, Linaria genistifolia, Artemisia absinthium, Thymus vulgaris, Scabiosa ochroleuca, Plantago lanceolata, Conyza canadensis, Stenactis annua, Setaria viridis, Sideritis montana, Lolium perenne, Euphorbia cyparissias, Euphorbia seguieriana.

\section{Értékelés}

A vesszős aggófú jelenlegi terjedési üteme lassabb, mint amit az ezredforduló éveiben történő megjelenését követően várni lehetett (vö. DANCZA \& KIRÁLY 2000). A kezdeti, kizárólag vasút menti megjelenését és tömeges fellépését követően az utóbbi 5-10 évben élőhelyspektruma kiszélesedőben van, terjedése gyorsforgalmi autóutak (főként autópályák) környezetére és antropogén hatásoknak erősen kitett termőhelyekre helyeződött át. Ez a megfigyelés egybevág más, főként nyugat-európai megállapításokkal, lásd pl. HEGER \& BöHMER (2005), EssL (2006), Milović \& PANDŽA (2014). Vasútvonalak menti terjedésének megtorpanása egy nem várt jelenség, különösen a kezdetben igen erős vitalitást mutató, elsők között megfigyelt, hatalmas egyedszámú állományok (Budapest: Kelenföld, Győr: Gyárváros), valamint a növény életformája és élőhelyi igényeinek ismeretében. Terjedési intenzitása a közép-európai térségben hektikus, a növény jóval intenzívebb térhódításra is képes lenne, mint azt a jelenlegi tapasztalatok mutatják. HEGER \& BöHMER (2006) arra figyelmeztet, hogy a klímaváltozási tendenciák kifejezetten kedvezőek a faj számára, a kontinentális területek felé való további terjedésének ugyanakkor komoly gátat szabhat, hogy hajtásai $-15^{\circ} \mathrm{C}$ alatt károsodnak. Hazánkban ilyen mértékű fagyok szinte minden évben előfordulnak, így ez is szerepet játszhat özönnövénnyé válásának elmaradásában. Megjegyzendő azonban, hogy előfordulásai elsősorban hőszennyezett élőhelyeken (pl. autóutak, városi ruderális területek) vannak, amelyek mentesek az erős fagyoktól, DANCZA (2012) szerint a november végi és december elejei havazások és tartós fagypont alatti hőmérséklet hatására a hajtások nem károsodnak. Győrött magunk is megfigyeltünk a téli időszak elején hóban, fagypont közeli hőmérsékletnél virágzásban és kaszatérlelésben lévő példányokat. Balogh L. (ex litt.) Szombathely-Herényben, szigorúan ellenőrzött kerti kísérleti körülmények között két évig nevelte a faj egyedeit. Beérett kaszatjait begyűjtötte, mégis, néhány kihulló termés nyomán a tő körül lévő csupasz talajon és nyílt gyepben is eredményes önvetést tapasztalt (ezt követően a néhány töves kerti állományt felszámolta).

A Senecio inaequidens hazánkban (a kezdeti prognózisok ellenére) nem vált gyorsan terjedő özönnövénnyé, és jelenleg még nem tartozik a terhes inváziós fajok közé. Megállapításaink szerint továbbra is fennáll a lehetősége annak, hogy (élőhelyspektrumának folyamatban lévő kiszélesedésével) a közeljövőben lelőhelyeinek száma ugrásszerűen megnövekszik. Megjelenésére a jelenlegi tendenciák alapján gyorsforgalmi autóutak mellett lehet számítani (SIRBU \& OPREA 2010, MiLOVIĆ \& PANDŽA 2014), ahol a megnövekedett járműforgalom segítségével szaporítóképletei a járművekre tapadva, majd azokról lehullva újabb populációkat hozhatnak létre. Újabban megfigyelt természetközeli (száraz erdők, legelők) és antropogén hatásoknak erő- 
sen kitett (kavicsbánya, köves pionír felszínek) élőhelyein terjedésének intenzívvé válása kevéssé valószínű, ilyen jellegű megfigyelései - egyelőre - átmenetinek látszanak.

Összefoglalva megállapítható, hogy a faj özönszerű terjedésének veszélye - az említett klimatikus okok miatt - hazánkban aktuálisan nem áll fenn. Térhódításának és élőhelyi viselkedésének folyamatos figyelemmel kísérése, valamint az eredmények rendszeres publikálását azonban szükségesnek tartjuk a jövőben.

\section{Köszönetnyilvánítás}

A szerzők köszönetüket fejezik ki Süveges Kristófnak és Szabó Rolandnak, hogy közöletlen florisztikai adataikat felhasználásra átengedték. Köszönettel tartozunk a Magyar Természettudományi Múzeum Növénytára munkatársának, Pifkó Dánielnek a herbáriumi lapok digitalizálásáért, valamint Takács Attilának, hogy elérhetővé tette számunkra a Debreceni Egyetem Herbáriumának gyűjteményi adatait. Továbbá köszönetünket fejezzük ki Balogh Lajosnak és Dancza Istvánnak a lelkiismeretes lektori munkájukért és személyes tapasztalataik megosztásáért.

\section{Irodalomjegyzék}

Anastasiu P. \& Negrean G. (2008): New alien plants to Romania. - Annals of the University of Craiova, the Agriculture Series 38 (B): 1-10.

BARABÁs S. \& RÉDEI T. (1998): Új adventív Senecio-faj Magyarországon. - Kitaibelia 3 (2): 257.

BALOGH L., DANCZA I. \& KIRÁLY G. (2004): A magyarországi neofitonok időszerű jegyzéke és besorolásuk inváziós szempontból. - In: MıнÁlY B. \& BoTTA-DuKáT Z. (szerk.), Biológiai inváziók Magyarországon. Özönnövények. A KvVM Természetvédelmi Hivatalának Tanulmánykötetei 9., TermészetBÚVÁR Alapítvány Kiadó, Budapest, pp. 61-92.

Bartha D., Király G., Schmidt D., Tiborcz V., Barina Z., Csiky J., Jakab G., Lesku B., SchmotZer A., VidéKi R., Vojtкó A. \& ZólYomi Sz. (2015): Magyarország edényes növényfajainak elterjedési atlasza. - Nyugatmagyarországi Egyetem Kiadó, Sopron, 329 pp.

BORNKAMM R. (2002): On the phytosociological affiliations of an invasive species Senecio inaequidens in Berlin. - Preslia 74: 395-407.

CsISZÁR Á. (szerk.) (2012): Inváziós növényfajok Magyarországon. - Nyugat-magyarországi Egyetem Kiadó, Sopron, 364 pp.

DANCZA I. (2012): Vesszős aggófú (Senecio inaequidens DC.). - In: CsiszÁR Á. (szerk.), Inváziós növényfajok Magyarországon. Nyugat-magyarországi Egyetem Kiadó, Sopron, pp. 289-293.

DANCZA I. \& KIRÁLY G. (2000): A Senecio inaequidens DC. előfordulása Magyarországon. - Kitaibelia 5 (1): 93-109.

DöVÉNYI Z. (szerk.) (2010): Magyarország kistájainak katasztere. - MTA Földrajztudományi Kutatóintézet, Budapest, 876 pp.

ERNST W.H.O. (1998): Invasion, dispersal and ecology of the South African neophyte Senecio inaequidens in The Netherlands: from wool alien to railway and road alien. - Acta Botanica Neerlandica 47 (1): 131-151.

EsSL F. (2006): Bemerkenswerte floristische Funde aus Wien, Niederösterreich, dem Burgenland und der Steiermark, Teil IV. - Linzer biologische Beiträge 38 (2): 1071-1103.

HegER T. \& BöHMER H.J. (2005): The invasion of Central Europe by Senecio inaequidens DC. - a complex biogeographical problem. - Erdkunde 59: 34-49.

HEGER T. \& BöHMER H.J. (2006): NOBANIS - Invasive Alien species Fact Sheet - Senecio inaequidens. From Online Database of the European Network on Invasive Alien Species. www.nobanis.org

Hohla M. (2011): Zwei Funde der Kleinen Seerose (Nymphaea candida) sowie weitere Beiträge zur Kenntnis der Flora von Oberösterreich. - Stapfia 95: 141-161.

JEHLík V. (1998): Senecio inaequidens a Atriplex heterosperma - nové invazní rostliny také na Slovensku. - In: Eliáš P. (ed.), Invázie a invázne organizmy (Abstrakty a program 2. vedeckej konferencie Nitra, 
18. - 20. november 1998). Slovenský národný komitét SCOPE \& Katedra ekológie FZKI SPU Nitra, Nitra, pp. 23.

KALIGARIČ M. (1992): Rastlinstvo Kraškega roba. - Proteus 54: 224-230.

KERÉNYI-NAGY V., BoRUS B., FERRÉ S.R. \& PENKSZA K. (2016): Senecio inaequidens DC. (Asteraceae) előfordulások Közép- és Délnyugat-Európában - Notes on the invasive narrow-leaved ragwort (Senecio inaequidens DC. Asteraceae) in Central and Southwest Europe - XI. Aktuális Flóra- és vegetációkutatás a Kárpátmedencében nemzetközi konferencia, 2016. február 12-14., Budapest, 164-165.

KirÁly G., BARANYAI-NAGY A., KeREKES Sz., KiRÁLY A. \& KoRDA M. (2009): Kiegészítések a magyar adventívflóra ismeretéhez IV. - Flora Pannonica 7: 3-31.

Kocián P. (2016): The first records of Senecio inaequidens along motorways in Poland and Slovakia. Acta Musei Silesiae, Scientiae Naturales 65: 129-133.

KoŠŤÁL J. (2012): Senecio inaequidens. - In: Elíšs P. jun. (ed.), Zaujímavejšie floristické nálezy. - Bulletin Slovenskej botanickej spoločnosti 34: p. 110.

KoŠŤÁL J. (2015): Senecio inaequidens. - In: Elí̂́š P. jun. (ed.), Zaujímavejšie floristické nálezy. - Bulletin Slovenskej botanickej spoločnosti 37: p. 233.

LÓPEZ-GARCíA M.C. \& MAILLET J. (2005): Biological characteristics of an invasive south African species. Biological Invasions 7: 181-194.

MASLO S. (2014): The urban flora of the city of Mostar (Bosnia \& Herzegovina). - Natura Croatica 23 (1): 101-145.

Milović M. \& PANDŽA M. (2014): New localities of Senecio inaequidens DC. in Croatia. - Natura Croatica 23 (1): 219-227

Pliszko A. (2017): A new record of Senecio inaequidens (Asteraceae) in Poland. - Acta Musei Silesiae, Scientiae Naturales 66: 177-180.

Radkowitsch A. (2003): Neophytic plants in Bavaria (Senecio inaequidens and Dittrichia graveolens). In: ZAJAC A., ZAJAC M. \& ZEMANEK B. (eds), Phytogeographical problems of synanthropic plants. Institute of Botany, Jagiellonian University, Cracow, pp. 47-61.

RIEZING N. (2012): Adatok a Győr-Tatai Kisalföld flórájához és vegetációjához. - Botanikai Közlemények 99 (1-2): 81-102.

SchмiDT D. (2010): Adatok a Kisalföld flórájának ismeretéhez II. - Botanikai Közlemények 97: 79-96.

SCHMidT D. \& BAUER N. (2005): Adatok a Kisalföld flórájának ismeretéhez I. - Botanikai Közlemények 92 $(1-2): 43-56$.

SiRBU C. \& OpREA A. (2010): Contribution to the Knowledge of the Alien Flora of Romania: Rudbeckia triloba L. and Senecio inaequidens DC. - Notulae Botanicae Horti Agrobotanici Cluj-Napoca 38 (1): 33-36.

Stevanović V., NiKeTić M. \& LAKUŠić D. (1990-1991): Distribution of the vascular plants in Yugoslavia (Sebia, Montenegro) and Macedonia. I. - Glasnik Instituta za botaniku i botaničke bašte "Jevremovac" Univerziteta u Beogradu 24-25: 33-54.

TERPó A. (1998a): A Senecio inaequidens DC. (S. reclinatus L.f.) Magyarország új adventív növénye. In: TERPó A. et al. (szerk.), Növényi ártalmak megelözése lakó- és mezőgazdasági környezetben. Konferencia előadás összefoglalók. GATE, Budapest-Gödöllő, pp. 134-135.

TERPó A. (1998b): A Senecio inaequidens (S. reclinatus) terjedése. - Botanikai Közlemények 85 (1-2): 158-159.

Vladimirov V. \& Petrova A. (2009): Senecio inaequidens (Asteraceae): a new alien species for the Bulgarian flora. - Phytologia Balcanica 15 (3): 373-375.

WAGENITZ G. (1987): Nachträge, Berichtigungen und Ergänzungen. - In: HEGI G. (ed), Illustrierte Flora von Mitteleuropa. Carl Hanser Verlag, München, Ed. 2, Vol. VI.4, pp. 1353-1452.

\section{Hivatkozott világháló oldalak:}

[1] http://www.eppo.int/INVASIVE_PLANTS/ias_lists.htm\#IAPList (Hozzáférés 2018.10.01.)

Beérkezett / received: 2018. 08.15. • Elfogadva / accepted: 2018. 11. 09. 